\title{
O zasadzie proporcjonalności D'Hondta jako relacji określonej na nierównolicznych populacjach
}

DOI: $10.19195 / 1643-0328.20 .6$

Słowa kluczowe: zbiory równoliczne, partycja, zasada proporcjonalności, podział mandatów, algorytm i zasada proporcjonalności D’Hondta

\section{Wprowadzenie}

Wybory parlamentarne 2015 roku po raz kolejny pokazały niedoskonałość stosowania prawa. Treść artykułu 96 Konstytucji RP stanowi, że „Wybory do Sejmu są powszechne, równe, bezpośrednie i proporcjonalne oraz odbywają się w głosowaniu tajnym”. W konfrontacji z realiami nie sprawdziło się to do końca, a dokładniej, nie sprawdziła się próba realizacji zasady proporcjonalności jako podstawowego narzędzia wykorzystywanego w proporcjonalnych systemach wyborczych ${ }^{1}$. Warto przypomnieć, że w opinii specjalistów

system proporcjonalny pojawił się w ustawodawstwie wyborczym [...] jako reakcja na niesprawiedliwości wynikające ze stosowania systemu większościowego. Z różnym powodzeniem wypróbowywano go we wszystkich niemal krajach Europy kontynentalnej, współcześnie łączy się zwłaszcza z systemami rozbicia wielopartyjnego [...], bo tylko wybory proporcjonalne pozwalają wejść do parlamentu większej liczbie partii politycznych ${ }^{2}$.

Co więcej, system ten wymaga przeprowadzenia tylko jednej tury wyborów, zawsze jest bowiem możliwy odpowiedni podział mandatów. Z praktyki wiadomo też, że sposób

${ }^{1}$ W piśmiennictwie przyjął się termin Proportional Representation(PR), zob. D. Nohlen, Prawo wyborcze i system partyjny. O teorii systemów wyborczych, Warszawa 2004, s. 55.

${ }^{2}$ L. Garlicki, Polskie prawo konstytucyjne - zarys wykładu, Warszawa 1999, s. 133. Według Raciborskiego (zob. J. Raciborski, Teoria demokracji a reguly wyborów, „Nauka” 2006, nr 3. s. 27-44) „nie jest oczywisty sens reguły proporcjonalności założony w Konstytucji RP”. Można bowiem ten zapis traktować zarówno jako odniesienie do proporcjonalnej reprezentacji, jak i do techniki ustalania wyników wyborów. Jednocześnie, jak zauważa Raciborski, „kontekst wskazuje, że zasada proporcjonalności ma taki sam status, jak zasada powszechności czy równości, idzie więc o wartość autoteliczną w obrębie wartości demokracji tego typu, a nie o aspekt techniczny [...]". 
rozdzielenia mandatów wymaga skomplikowanych i na ogół nieczytelnych algorytmów ilościowych ${ }^{3}$. Jak zostanie przedstawione w dalszej części artykułu, p r o p or cj o n aln o ści wyborczej nie można utożsamiać z proporcjonalnością powszechnie rozumianą w matematyce czy fizyce.

Nieprzypadkowo zresztą największy udział w pracach nad proporcjonalnym systemem wyborczym odnotowali właśnie matematycy ${ }^{4}$. To oni zaproponowali różne sposoby realizacji konwersji parytetu liczba otrzymanych głosów - liczba uzyskanych mandatów, które wykorzystywane były w różnych okresach przez większość państw europejskich.

Jedno nie podlega dyskusji - żadna z zaproponowanych metod nie jest doskonała, nie doczekała się powszechnego stosowania we współczesnym świecie, wypierając pozostałe. Każda natomiast ma wadę, skutkującą tym, że proporcjonalność wyborcza nie jest proporcjonalnością, o czym wspomniano wcześniej ${ }^{5}$. W takim razie może być, i w ręku każdego ustawodawcy jest, sprytnym narzędziem, które niezależnie od preferencji wyborczych jest w stanie wpłynąć na podział mandatów, a więc na realny wynik wyborów ${ }^{6}$. Wobec powyższego tym bardziej dziwi fakt raczej trywialnego pojmowania przez pewne rzesze politologów, prawników, polityków potrzeby stosowania takich algorytmów oraz brak ich gruntownego zrozumienia ${ }^{7}$. Na ogół w wyjaśnieniu każdego z używanych algorytmów wystarcza bowiem stwierdzenie typu: „belgijski matematyk Victor D’Hondt założył, że liczbę głosów oddanych na każdą z list dzieli się przez kolejne

3 Szczegóły zobacz w pracy J.W. Holubiec, J.W. Mercik, Techniki i tajniki głosowania, Warszawa 1992, s. 28.

4 Na potrzebę stworzenia proporcjonalnego systemu wyborczego po raz pierwszy (w 1785 r.) zwrócił uwagę francuski matematyk Jean Antoine de Condorcet (1743-1794). Idee te następnie rozwinął jego rodak Joseph Diaz Gergonne (1771-1859) i inni, wśród nich André Sainte-Lagűe, belgijski matematyk i prawnik Victor D’Hondt (1841-1901) oraz niemiecki matematyk Hare Niemeyer (1931-2007).

5 Jest to jedna ze znanych ułomności demokratycznego wyboru zauważona już przez Kennetha J. Arrowa w udowodnionym przez niego słynnym twierdzeniu o możliwości, na co zwraca uwagę w swojej pracy Raciborski, zob. J. Raciborski, op. cit., s. 29.

${ }^{6}$ Coraz częściej przy tej okazji używa się sformułowania inżynieria wyborcza. Zjawiska towarzyszące nadużywania metod inżynierii wyborczej są $\mathrm{z}$ uwagą rejestrowane $\mathrm{i}$ analizowane przez socjologów i politologów. Szczególnie jeśli chodzi o zdarzenia mające miejsce na początku polskiej odnowy, zob.: Ibidem, s. 30-32, zob. L. Jaczynowski, Mechanizmy organizujące demokracje, „Rocznik Naukowy Wydziału Zarządzania w Ciechanowie” IX, 2015 (tematyce tej poświęcona jest cała praca).

7 Jak wspomniano, nie dotyczy to wszystkich, o czym może świadczyć prowadzony w tym zakresie, zwłaszcza przez Jacka Hamana, dyskurs naukowy, zob. J. Haman, Podział mandatów pomiędzy okręgi wyborcze $w$ świetle teorii sprawiedliwego podziału, „Przegląd Sejmowy” 2002, nr 1, s. 10-33; idem, Badania metod głosowania: dedukcja, indukcja, symulacja, „Decyzje” 2006, nr 6; idem, Degresywnie proporcjonalny podział mandatów w Parlamencie Europejskim. Propozycja nowego rozwiązania, „Decyzje” 2007, nr 8, czy Bartłomieja Michalaka, zob. B. Michalak, M. Pierzgalski, Wpływ metody przeliczania głosów na mandaty na wyniki wyborów do Sejmu Rzeczypospolitej Polskiej z dnia 23 września 2001 r., [w:] Polska we współczesnym świecie. Między zaściankiem a przestrzeniq wolności, red. A. Kasińska-Metryka, R. Bäcker, Toruń 2007, s. 205-219 czy Michała Pierzgalskiego zob. M. Pierzgalski, Zastosowanie wybranych metod statystycznych w badaniach systemów wyborczych, „Studia Wyborcze” 9, 2010, s. 39-66. 
liczby naturalne"8. Dalej przedstawia się proste symulacje liczbowe działania wybranego algorytmu i na tej podstawie formułuje się konkluzje typu: „doktryna i praktyka potwierdzają, że system D’Hondta preferuje partie najsilniejsze. Dotyczy to także systemu Saint Lagüe’a $\mathrm{w}$ wersji z pierwszym dzielnikiem 1,4"'. Brakuje natomiast tego, co jest najważniejsze - dlaczego wybrano taką metodę konwersji, ale także formalnego dowodu matematycznego potwierdzającego określoną własność zastosowanego algorytmu ${ }^{10}$.

Kwestie te dokładnie będą poruszane w niniejszej pracy. W tym celu należy skonstruować matematyczny model zdefiniowanej zasady proporcjonalności oparty na pojęciu relacji określonej na dwóch nierównolicznych populacjach. Zdefiniowanie algorytmu wykorzystującego pomysł D’Hondta pozwoli wykazać, że metoda przydzielania mandatów wykorzystująca jego podejście spełnia tę zasadę. Jednocześnie zostanie udowodniona najważniejsza własność tej metody — jej tendencja do nadreprezentatywności w procedurze obsadzania miejsc. Całość rozumowania zostanie zilustrowana niezbędnymi symulacjami numerycznymi, aby w ten sposób zwrócić uwagę na rolę zdarzeń brzegowych, jakie mogą towarzyszyć tej metodzie i mają wpływ na końcowe wyniki jej zastosowania.

Takie przedstawienie problematyki towarzyszącej proporcjonalnemu systemowi wyborczemu należy się zarówno demokracji, jak i wszystkim jej beneficjentom - wyborcom i politykom.

${ }^{8}$ B. Szepietowska, Zasada proporcjonalności w prawie wyborczym - wybrane systemy rozdziału mandatów, http://biurose.sejm.gov.pl/teksty/i-695.htm (dostęp:13.12.2015).

9 Ibidem.

${ }^{10}$ W literaturze światowej problematyka badań nad Proportional Representation datowana jest od drugiej połowy XX wieku - od ukazania sie pionierskiej pracy Steina Rokkana, zob. S. Rokkan, Elections: electoral systems, [w:] International Encyclopedia of the Social Sciences, red. D.L. Sills, New York: Macmillan and Free Press 1968. Przedmiotem szczególnej analizy stał się problem progu wyborczego (threshold) w kontekście stosowania różnych algorytmów rozdzielania mandatów. W kolejnej pracy D.W. Rae, V. Hanby, J. Loosemore, Thresholds of representation and thresholds of exclusion: an analytic note on electoral systems, „Comparative Political Studies” 1971, nr 3, s. 479-488, Douglas Rae, Victor Hanby oraz John Loosemore doprecyzowali pojęcie progu, posługując się progiem wykluczenia (threshold of exclusion) oraz funkcją wypłaty (payoff function). Podsumowania tej tematyki badań dokonano w pracy A. Lijphart, R.W. Gibberd R., Thresholds and payoff in list systems of proportional representation, „European Journal of Political Research" 1977, nr 5, s. 219-244, gdzie Arend Lijphart i Robert Gibberd dokonali weryfikacji uzyskanych wcześniej wyników i ich uogólnienia. W latach 90. XX wieku przedmiotem badań był proble m z a o k rą gleń, zob. M. Balinski, S.T. Rachev, Rounding proportions: rules of rounding, „Numer. Funct. Anal. and Optimiz." 1993, nr 14, s. 475-501 oraz próba globalnej matematyzacji zjawiska Proportional Representation, zob. J. Petit, Térouanne E., A theory of proportional representation, „SIAM J. Disc. Math.” 3, 1990, nr 1, s. 116-139, zapoczątkowana znakomitą książką Balinskiego i Younga, zob. M. Balinski, H.P. Young, Fair Representation, Meeting the Ideal of One Man One Vote, New Haven 1982. Badania obejmujące PR trwają nieprzerwanie. Praca M. Balinski, Equitable representation and recruitment, „Ann Oper Res” 2007, nr 149, s. 27-36 pokazuje, że w badaniach nad zjawiskiem PR sięga się po coraz bardziej wyrafinowane metody matematyczne typu: teoria grafów, programowanie całkowite i inne metody matematyki dyskretnej, a nawet teorię prawdopodobieństwa, zob. L. Heinrich, F. Pukelsheim, U. Schwingenschlögl, On stationary multiplier methods fot the rounding of probabilities and the limiting law of the Sainte-Lagüe divergence, „Statistics \& Decisions" 2005, nr 23, s. 117-129. 


\section{Matematyczne sformułowanie problemu}

Dane są dwa skończone zbiory: W złożony z $n$ elementów oraz $m$-elementowy zbiór M. Przyjęto, że zbiory te sa nieró wnoliczne ${ }^{11}$, co oznacza, że $n \neq m^{12}$, a dalej, że dla ustalonego $k \geq 2$ znany jest podział zbioru $\mathbf{W}$ postaci $^{13}$

$$
W=W_{1} \cup W_{2} \cup \ldots \cup W_{K} \text {, }
$$

gdzie zbiory $\mathbf{W}_{\mathbf{j}}$ są parami rozłączne, czyli $\mathbf{W}_{\mathbf{r}} \cap \mathbf{W}_{\mathbf{s}}=\varnothing$ ile $r \neq s$. Można więc przyjąć, że znana jest liczebność każdego elementu $\mathbf{W}_{\mathbf{j}}$ tego podziału, które zostaną oznaczone odpowiednio przez $n_{j}$. Wprost z założenia na temat podziału można napisać

$$
n=n_{1}+n_{2}+\ldots+n_{k} \text {. }
$$

Dzieląc ostatnią równość stronami przez liczebność zbioru $\mathbf{W}$ otrzymuje się

$$
1=\frac{n_{1}}{n}+\frac{n_{2}}{n}+\ldots+\frac{n_{k}}{n}
$$

Przyjmując, że $p_{j}=\frac{n_{j}}{n}$ oraz wykorzystując powyższą równość, otrzymuje się ilościowy opis przyjętej struktury zbioru $\mathbf{W}$ dany wektorem $\mathbf{w}$ postaci

$$
w=\left(p_{1}, p_{2}, \ldots, p_{k}\right), g d z i e 0<p_{j}<1 \text { oraz } p_{1}+p_{2}+\ldots+p_{k}=1 .
$$

Dalej, bez zmniejszania ogólności rozumowania trzeba założyć, że przyjęto takie uporządkowanie składowych wektora w, zwane dalej jego po działem, że

$$
p_{k}<p_{k-1}<\ldots<p_{2}<p_{1} .
$$

Uwaga 1. Zasada abstrakcji ${ }^{14}$ opisuje zwiąek pomiędzy partycją a relacją równoważności określona na zbiorze. Dlatego strukturę zbioru $W$ dana zdefiniowanym wyżej podziałem można opisać relacja równoważności $R_{W}$. Wtedy każdy element $\boldsymbol{W}_{\boldsymbol{j}}$ jest atomem partycji generowanej przez tę relację. Dokładniej mamy wtedy

$$
w_{1} R_{w} w_{2} \Leftrightarrow w_{1}, w_{2} \in W_{j} \text { dla pewnego } j=1,2, \ldots, k,
$$

Spróbujemy teraz przenieść strukturę zbioru W, utożsamianą na mocy Uwagi 1 z pewną relacją równoważności, na zbiór $\mathbf{M}$. Efektem tego powinna być też relacja równoważności, powiedzmy $R_{M}$, od której powinniśmy oczekiwać co najmniej tego, że ge-

11 Wyjaśnienie tego terminu można znaleźć na przykład w K. Kuratowski, Wstęp do teorii mnogości i topologii, Warszawa 1973, s. 60.

12 W zastosowaniach liczba $n$ wskazuje na liczbę wyborców, natomiast $m$ na liczbę mandatów do rozdzielenia.

13 Taki podział nazywa się p a r y cj a z bi or u, zob. R. Rębowski, Matematyka dyskretna dla informatyków, Legnica 2008, s. 88.

${ }^{14}$ Ibidem. 
neruje tę samą liczbę atomów co relacja $R_{W}{ }^{15}$. Oznacza to, że z istnienia takiej relacji będzie wynikał podział typu partycja zbioru $\mathbf{M}$ postaci

oraz

$$
M=M_{1} \cup M_{2} \cup \ldots \cup M_{K}, g d z i e M_{r} \cap M_{s}=\emptyset \text { dla } r \neq s,
$$

$$
m_{1} R_{M} w_{2} \Leftrightarrow m_{1}, m_{2} \in \boldsymbol{M}_{\mathbf{j}} \text { dla pewnego } j=1,2, \ldots, k .
$$

Ponadto na zbiorze $\mathbf{W}$ powinna być określona relacja $R$ o wartościach w zbiorze $\mathbf{M}$, czyli $R \subset \mathbf{W} \times \mathbf{M}$, dla której powinniśmy mieć:

$w R m \Leftrightarrow$ jeśli dla pewnego $j, w \in W_{j}$, to $m \in M_{j}$ i na odwrót.

Jak dobrze wiadomo, z definicji relacji $R$ wynika, że relacja $R_{M}$ generowana jest przez $R$, bowiem wtedy rodzina zbiorów

$$
M_{j}=R\left(W_{j}\right) \text { dla } j=1,2, \ldots, k
$$

jest partycją zbioru M.

Następnie potrzebna będzie następująca definicja wyjaśniającą w tej pracy pojęcie proporcjonalności.

Definicja (zasada proporcjonalności). Niech dane będa dwa zbiory $\boldsymbol{W}, \boldsymbol{M}$ oraz relacje $R_{w}$ $R$ określone jak wyżej. Powiemy, że relacja $R$ realizuje zasadę proporcjonalności, jeśli obrazem wektora $\boldsymbol{w}=\left(p_{1}, p_{2}, \ldots, p_{k}\right)$ jest wektor $\boldsymbol{m}=\left(\tilde{p}_{1}, \widetilde{p}_{2}, \ldots, \widetilde{p}_{k}\right), g d z i e$ :

1. $\tilde{p}_{j}=\frac{\left|M_{j}\right|}{m}, j=1,2, \ldots, k,(|M|)$ oznacza moc zbioru),

2. zachodza następujące dwie nierówności:

$$
p_{1} \leq \tilde{p}_{1}, \tilde{p}_{k} \leq p_{k}
$$

W tym miejscu można sformułować główny problem pracy.

Problem. Skonstruować przykład relacji realizującej zasadę proporcjonalności.

\section{Algorytm D'Hondta}

\section{Przypadek zbiorów równolicznych}

Warto zacząć od ważnej uwagi, która tłumaczy złożoność konstrukcji pozwalającej rozwiązać Problem. Jednocześnie zwróci to uwagę na istotę badanego zagadnienia, podkreślając fakt właściwego znaczenia i rozumienia zjawiska proporcjonalności występującego w PR.

Uwaga 2. Przypuśćmy, wbrew założeniom poczynionym $w$ rozdziale 2 , że zbiory $\boldsymbol{W}$ i $\boldsymbol{M}$ sa równoliczne. Biorąc wtedy takie, że

$$
\left|M_{j}\right|=n_{j}, \text { dla } j=1,2, \ldots, k
$$

\footnotetext{
15 Warto pamiętać, że zasada abstrakcji działa w obie strony.
} 
z założenia o równoliczności obu zbiorów otrzymamy partycję zbioru $\mathbf{M}, k$ tóra:

1. definiuje relację równoważności $R_{M}$,

2. pozwala zdefiniować relacje $R \subset \boldsymbol{W} \times \boldsymbol{M}$, dla której spełniona jest zasada proporcjonalności.

Oznacza to, że w przypadku równoliczności dwóch zbiorów rozwiązanie Problemu jest trywialne. Oczywiście, przedstawione powyżej rozumowanie nie jest prawdziwe w sytuacji zbiorów nierównolicznolicznych. W takim przypadku można by spróbować postępować następująco: dla danego $j=1,2, \ldots, k$, definiujemy podzbiór $\mathbf{M}_{\mathbf{j}} \subset \mathbf{M}$, gdzie $\left|\mathbf{M}_{\mathbf{j}}\right|=p_{j}|\mathbf{M}|$. Zauważmy, że już na wstępie pojawia się problem — liczba $p_{j}|\mathbf{M}|$ nie musi być całkowita. $Z$ technicznego punktu widzenia kłopot ten łatwo wyeliminować - wystarczy tak zadysponować procesem zaokrąglenia, aby uzyskać efekt opisany zasadą proporcjonalności. Sytuacja ulega zmianie, kiedy proces zaokrąglenia może nie być możliwy ze względu na dodatkowe okoliczności (pozamatematyczne) wynikające z interpretacji opisywanej w Problemie sytuacji, o czym będzie mowa w następnym rozdziale. Okaże się wtedy, że opisywaną powyżej procedurę będzie trzeba odrzucić jako nieakceptowalną. Tłumaczy to, dlaczego do rozwiązania Problemu sięga się po metody bardziej wyrafinowane.

\section{Algorytm D'Hondta}

Autor zaprezentuje w wersji czysto matematycznej pomysł należący do matematyka belgijskiego Victora D’Hondta ${ }^{16}$. Wykaże, że za pomocą tego algorytmu można zrealizować zasadę proporcjonalności przy ograniczonej możliwości jej oprotestowania z powodów czysto niematematycznych.

Przypuśćmy, że dane są dwa nierównoliczne skończone zbiory $\mathbf{W}, \mathbf{M}$ oraz relacja $R_{w}$ generująca wektor $\boldsymbol{w}=\left(p_{1}, p_{2}, \ldots, p_{k}\right)$ jak zostało to przedstawione w rozdziale 2 . Weźmy liczbę $d \geq\left[\frac{m}{k}\right]^{17}$ oraz zdefiniujmy następującą macierz $\mathrm{D}=\left[\mathrm{d}_{\mathrm{ij}}\right]$, gdzie odpowiednio wiersz pierwszy składa się ze współrzędnych wektora $w$, następne z jego kolejnych j-ilorazów, dla $j=1,2, \ldots, n$.

- krok 1 algorytmu: $\mathrm{z}$ kolumny o numerze 1 macierzy $\mathbf{D}$ wybieramy wszystkie kolejne elementy, które są nie mniejsze od pozostałych elementów macierzy. $Z$ założenia istnieje taki co najmniej jeden $-p_{1}$. Wybrane elementy wykreślamy z macierzy i czynność powtarzamy dla kolumny drugiej, o ile liczba wybranych elementów jest mniejsza od $m$. Krok pierwszy kończymy na powtórzeniu czynności w przypadku pozostałych kolumn, o ile liczba wybranych elementów jest mniejsza od $m$. W ten sposób z macierzy $\mathbf{D}$ wybierzemy co najmniej $k$ elementów uporządkowanych malejąco. Jeśli liczba wybranych elementów jest równa $m$ algorytm kończymy, jeśli mniejsza, przystępujemy do realizacji kroku 2.

16 Pomysł narodził się w 1878 roku jako propozycja procedury podziału mandatów między kandydatów z list komitetów wyborczych w wyborach o ordynacji proporcjonalnej, znanej jako metoda D’Hondta.

17 Dla danej liczby rzeczywistej $r$, symbol $[r]$ oznacza jej c zęść c ałkowitą, czyli największą liczbę całkowitą nieprzekraczającą r, zob. R.L. Graham, D.E. Knuth, O. Patashnik, Matematyka konkretna, Warszawa 2002, s. 90. 
- krok 2 algorytmu: przetwarzamy na zasadzie kroku 1 pozostałe elementy macierzy, zaczynając od kolumny pierwszej.

Warto zauważyć, że wskutek co najwyżej $d$ iteracji opisanych w krokach 1 oraz 2 otrzymamy malejący ${ }^{18}$ ciąg liczb

$$
e_{1}>e_{2}>\ldots>e_{m}
$$

o tej własności, że dla każdego elementu $d_{i j}$ pozostałego w macierzy $\mathbf{D}, e_{m}>d_{i j}$.

- krok 3 algorytmu: definiujemy funkcję wyboru

$$
\chi:\left\{e_{1}, e_{2}, \ldots, e_{m}\right\} \rightarrow \mathbf{M},
$$

a za jej pomocą partycję zbioru M, gdzie

$$
\chi(\text { ej }) \in \mathbf{M}_{\mathbf{i}} \Leftrightarrow \text { liczba } e_{j} \text { wybrana jest } z \text { i-tej kolumny macierzy } \mathbf{D} \text {, }
$$

dla każdego $j=1,2, \ldots, m$ oraz $i=1,2, \ldots, k$.

Mając zdefiniowaną w powyższy sposób partycję możemy skonstruować wektor m odpowiadający wektorowi $\mathbf{w}$ w postaci

$$
\boldsymbol{m}=\left(\frac{\left|M_{1}\right|}{m}, \frac{\left|M_{2}\right|}{m}, \ldots, \frac{\left|M_{k}\right|}{m}\right)=\left(\widetilde{p}_{1}, \widetilde{p}_{2}, \ldots, \widetilde{p}_{k}\right),
$$

Poniższy przykład ilustruje sposób przebiegu powyższego algorytmu.

Przykład1 (pierwsza symulacja).Przyjmijmy, że $|\boldsymbol{M}|=10, k=3$ oraz $\boldsymbol{w}=\left(p_{1}, p_{2}, p_{3}\right)=(0,6 ; 0,3 ; 0,1)$. Wtedy liczba $d=4$ oraz macierz $\mathbf{D}$ (jej kolejne wiersze) będzie miała postać:

$$
\begin{gathered}
d_{1 j}=0,6 ; 0,3 ; 0,1 ; d_{2 j}=0,3 ; 0,15 ; 0,05 ; d_{3 j}=0,2 ; 0,1 ; 0,0333 ; d_{4 j}=0,15 ; 0,075 ; 0,025 ; \\
d_{5 j}=0,12 ; 0,06 ; 0,02 ; d_{6 j}=0,1 ; 0,05 ; 0,0163 .
\end{gathered}
$$

W wyniku przeprowadzenia pierwszego kroku algorytmu otrzymamy ciag

$$
(0,6 ; 0,3 ; 0,3) \text {. }
$$

Wykonujemy teraz pierwsza iteracje $w$ ramach kroku drugiego. Otrzymamy wtedy ciag $(0,2 ; 0,15 ; 0,15)$.

Aby skonstruować za pomoca funkcji wyboru partycje zbioru 10-elementowego, potrzeba jeszcze czterech wyrazów. Należy zatem wykonać kolejna iterację w ramach kroku drugiego. Daje to ciag

$$
(0,12 ; 0,1 ; 0,1 ; 0,1) \text {. }
$$

Wybrany $w$ ten sposób nierosnący ciag ma postać

$$
(0,6 ; 0,3 ; 0,3 ; 0,2 ; 0,15 ; 0,15 ; 0,12 ; 0,1 ; 0,1 ; 0,1) \text {. }
$$

\footnotetext{
18 Dla uproszczenia założono, że wektor $\boldsymbol{w}$ składa się ze współrzędnych malejących.
} 
Oznaczmy przez $\mathbf{M}_{\mathbf{1}}, \boldsymbol{M}_{\mathbf{2}}, \boldsymbol{M}_{\mathbf{3}}$ atomy partycji zbioru $\boldsymbol{M}$. Z definicji funkcji wyboru zastosowanej do otrzymanego wyżej ciagu widać, że:

$$
\left|M_{1}\right|=6,\left|M_{2}\right|=3,\left|M_{3}\right|=1 \text {. }
$$

Dlatego wektor $\boldsymbol{m}$ będzie miał postać

$$
\boldsymbol{m}=(0,6 ; 0,3 ; 0,1) \text {. }
$$

Uwaga 3. Przypuśćmy, że przy danych z Przykładu 1 zbiór M jest 9-elementowy. Wtedy ostatnia sekwencja ciąu będzie miała postać (0,12;0,1;0,1). Istnieja teraz dwie jednakowe wartości liczbowe wybrane z trzech kolumn macierzy D. Gdyby pominąć kolumnę trzecia, to atom $\mathbf{M}_{3}$ byłby pusty, co jest niemożliwe. Dlatego $w$ takiej sytuacji (równe wartości) trzeba do algorytmu wprowadzić poprawkę w postaci następującej klauzuli: jeśli ciąg utoworzony w wyniku zastosowania algorytmu kończy się wyrazami o jednakowej wartości, to o wartości funkcji wyboru dla tych wartości decyduje:

- albo fakt, że dotychczas dany atom partycji był niepusty. Wtedy spośród co najmniej takich dwóch, w pierwszej kolejności wybierany jest ten, który odpowiada większej wartości $p_{j}$,

- albo fakt, że wszystkie atomy sa niepuste. Wtedy dla takiej wartości funkcja wyboru wskazuje kolejne kolumny odpowiadajace malejaccym wartościom ciagu $p_{j}$.

Dlatego, przy takiej modyfikacji Przykładu 1, atom $\boldsymbol{M}_{3}$ jest jednoelementowy, $\left|\boldsymbol{M}_{\mathbf{1}}\right|=6$, natomiast $\left|\boldsymbol{M}_{2}\right|=2$. W tym przypadku otrzymamy wektor $\boldsymbol{m}=(0,666 ; 0,222 ; 0,111)$.

Kolejny przykład pokazuje, że z innego powodu co najmniej jeden $\mathrm{z}$ atomów konstruowanej partycji może być pusty.

Przykład 2 (druga symulacja). Niech $k=2$, wektor $\boldsymbol{w}=(0,95 ; 0,05)$. Przyjmijmy, że liczebność zbioru M wynosi 5. Przy tych założeniach macierz $\mathbf{D}$ (jej kolejne wiersze) będzie postaci

$d_{1 j}=0,95 ; 0,05 ; d_{2 j}=0,475 ; 0,025 ; d_{3 j}=0,316 ; 0,016 ; d_{4 j}=0,275 ; 0,0125 ; d_{5 j}=0,19 ; 0,01$. Dlatego wynikiem algorytmu będzie ciąg wybrany tylko z pierwszej kolumny macierzy $\mathbf{D}$, czyli $(0,95 ; 0,475 ; 0,316 ; 0,275 ; 0,19)$. Pokazuje to, że atom $\boldsymbol{M}_{\mathbf{2}}$ jest pusty.

Dalej przyjmiemy kolejne założenie modyfikujace nasz algorytm: w sytuacji podobnej do powyższej ciagg wynikowy będzie zmodyfikowany do postaci (0,95;0,475;0,316;0,275;0,05), co oznacza, że $\left|\boldsymbol{M}_{2}\right|=1$ i odpowiedni wektor będzie miał postać $\boldsymbol{m}=(0,8 ; 0,2)$. Jak zobaczymy dalej, jedynie $w$ takiej sytuacji może zdarzyć się, że $\widetilde{p}_{1}<p_{1}$. Jasne jest, że sytuacja opisana $w$ symulacji drugiej spowodowana jest duża dysproporcja pomiędzy wartościami $p_{1}, p_{2}$ oraz za mała wartościa $|\mathbf{M}|$. Wystarczy tę wartość odpowiednio zwiększyć i problem zniknie, jak to pokazano w kolejnej symulacji.

Przykład 3 (trzecia symulacja). Przyjmijmy, że $|\boldsymbol{M}|=20, k$ oraz $\boldsymbol{w}$ sq jak wyżej. Tym razem macierz $\mathbf{D}$ ma postać jak niżej $i$ widać, że ostatnim wyrazem skonstruowanego ciagu będzie liczba 0,05 z drugiej jej kolumny. Teraz $|\boldsymbol{M}|=1$ oraz odpowiedni wektor będzie miat postać

$$
\boldsymbol{m}=(0,95 ; 0,05)
$$


co pokazuje, że $p_{1} \leq \tilde{p}_{1}$.

$\mathbf{D}=\left[\mathrm{d}_{\mathrm{ij}}\right]$, gdzie:

$$
d_{1 j}=0,95 ; 0,05 ; d_{2 j}=0,475 ; 0,025 ; d_{3 j}=0,316 ; 0,016 ; d_{4 j}=0,275 ; 0,0125 ;
$$

$d_{5 j}=0,19 ; 0,01 ; d_{6 j}=0,158 ; 0,0083 ; d_{7 j}=0,135 ; 0,007 ; d_{8 j}=0,118 ; 0,0062 ; d_{9 j}=0,1055$; 0,$0055 ; d_{10 j}=0,095 ; 0,005 ; d_{11 j}=0,086 ; 0,0045 ; d_{12 j}=0,079 ; 0,004 ; d_{13 j}=0,073 ; 0,0038$; $d_{14 j}=0,067 ; 0,0035 ; d_{15 j}=0,063 ; 0,0033 ; d_{16 j}=0,059 ; 0,0031 ; d_{17 j}=0,055 ; 0,0029$; $d_{18 j}=0,052 ; 0,0027 ; d_{19 j}=0,05 ; 0,0026 ; d_{20 j}=0,0475 ; 0,0025$.

\section{Podstawowe twierdzenie}

Warto zająć się w tym miejscu uogólnieniem uwag sformułowanych w poprzednim rozdziale, analizując kolejne symulacje. Zaczniemy od następującego lematu.

Lemat. Przypuśćmy, że dla $k=2$ algorytm D'Hondta można przeprowadzić. Wtedy majac partycję zbioru $\mathbf{W}$ można skonstruować partycje zbioru $M$. Ponadto każdemu wektorowi gdzie $\boldsymbol{w}=\left(p_{1}, p_{2}\right)$, gdzie $p_{2}<p_{1}$, można przyporzadkować wektor $\boldsymbol{m}=\left(\tilde{p}_{1}, \widetilde{p}_{2}\right), \dot{z} e p_{1} \leq \tilde{p}_{1}$.

Dowód. Przykład drugiej symulacji pokazuje, że założenie lematu jest istotne - jeśli algorytm w swojej podstawowej postaci nie uda się, i przeprowadzi się jego poprawkę, to teza Lematu nie będzie prawdziwa. Dlatego dalej założymy, że dla liczby $m \geq 2$ algorytm wykonał się, co oznacza, że powstało przyporządkowanie:

$$
\left(p_{1}, p_{2}\right) \rightarrow\left(\tilde{p}_{1}, \tilde{p}_{2}\right), g d z i e p_{2}<p_{1}
$$

Niech $n$ oznacza liczbę iteracji algorytmu, czyli najmniejszą liczbę naturalną, która jest niezbędna, aby na podstawie wektora $w=\left(p_{1}, p_{2}\right)$ można było skonstruować partycję $m$-elementowego zbioru $\mathbf{M}$ opisaną wektorem $\boldsymbol{m}=\left(\tilde{p}_{1}, \widetilde{p}_{2}\right)$. Aby uporządkować w ciąg monotoniczny elementy macierzy $\mathbf{D}$ zdefiniujemy następującą rodzinę zbiorów:

$$
A_{1}=\left\{j \in N: \frac{p_{1}}{j} \geq p_{2}\right\}, A_{2}=\left\{j \in N: \frac{p_{2}}{j} \geq \frac{p_{1}}{j_{1}}\right\}, g d z i e j_{1}=\max _{1},
$$

i ogólnie

$$
\begin{gathered}
A_{1}=\left\{j \in N: \frac{p_{1}}{j} \geq \frac{p_{2}}{j_{i-1}}\right\}, \text { dla nieparzystego } i ; \\
A_{1}=\left\{j \in N: \frac{p_{2}}{j} \geq \frac{p_{1}}{j_{i-1}}\right\}, \text { dla parzystego } i
\end{gathered}
$$

gdzie $j_{i}=\max A_{i}{ }^{19}$ dla $i=1,2, \ldots, n$.

Daje to następujące uporządkowanie elementów macierzy $\mathbf{D}$ :

$$
p_{1}>\frac{p_{1}}{2}>\ldots>\frac{p_{1}}{j_{1}} \geq p_{2} z \text { definicji } A_{1}
$$

$19 \max A$ oznacza element największy zbioru $A$. 


$$
\begin{gathered}
p_{2}>\frac{p_{2}}{2}>\ldots>\frac{p_{2}}{j_{2}} \geq \frac{p_{1}}{j_{1}+1} z \text { definicji } A_{2}, \\
\frac{p_{1}}{j_{1}+1}>\frac{p_{1}}{j_{1}+2}>\ldots>\frac{p_{1}}{j_{1}+k_{1}} \geq \frac{p_{2}}{j_{2}+1} z \text { definicji } A_{3}, \\
\frac{p_{2}}{j_{2}+1}>\frac{p_{2}}{j_{2}+2}>\ldots>\frac{p_{2}}{j_{2}+k_{2}} \geq \frac{p_{1}}{j_{3}+1} z \text { definicji } A_{4}, \text { itd. }
\end{gathered}
$$

Wtedy pojawia się odpowiednio

$$
\frac{j_{1}+1}{j_{2}} \geq \frac{p_{1}}{p_{2}}, \frac{j_{1}+k_{1}+1}{j_{2}+k_{2}} \geq \frac{p_{1}}{p_{2}},
$$

i ogólnie, dla ostatniego kroku iteracji

$$
\frac{j_{1}+k_{1}+k_{3}+\ldots+k_{n-1}+1}{j_{2}+k_{2}+k_{4}+\ldots+k_{n}} \geq \frac{p_{1}}{p_{2}}
$$

Ale lewa strona ostatniej nierówności, z definicji funkcji wyboru, reprezentuje iloraz $\frac{\tilde{p}_{1}}{\widetilde{p}_{2}}$. Dlatego $\frac{\underline{p}_{1}}{\widetilde{p}_{2}} \geq \frac{p_{1}}{p_{2}}$. Pozostaje zauważyć, że ponieważ $p_{1}+p_{2}=\widetilde{p}_{1}+\widetilde{p}_{2}=1$, ostatnią zależność można zapisać równoważnie jako

co dowodzi, że $\widetilde{p}_{1} \geq p_{1}$.

$$
\frac{\widetilde{p}_{1}}{1-\widetilde{p}_{1}} \geq \frac{p_{1}}{1-p_{2}}
$$

Zaprezentowana w dowodzie lematu metoda zliczania wartości funkcji wyboru dla algorytmu D’Hondta na przykładzie dwuelementowej partycji zbioru $\mathbf{M}$ działa również dla dowolnej wartości $k$. Ze względu na złożoność analizowanej sytuacji zaprezentowano jedynie przykład kiedy $k=3$. Zakładając, że algorytm nie wymaga żadnej poprawki, efektem jego zastosowania na odpowiedniej macierzy $\mathbf{D}$ będzie ciąg, którego początek przedstawiono poniżej.

$$
\begin{gathered}
p_{1}>\frac{p_{1}}{2}>\ldots>\frac{p_{1}}{j_{1}} \geq p_{2}>\frac{p_{2}}{2}>\ldots>\frac{p_{2}}{j_{2}} \geq p_{3}>\frac{p_{3}}{2}>\ldots>\frac{p_{3}}{j_{3}} \geq \\
\frac{p_{1}}{j_{1}+1}>\frac{p_{1}}{j_{1}+2}>\ldots>\frac{p_{1}}{j_{1}+k_{1}} \geq \frac{p_{2}}{j_{2}+1}>\frac{p_{2}}{j_{2}+2}>\ldots>\frac{p_{2}}{j_{2}+k_{2}} \geq \\
\frac{p_{3}}{j_{3}+1}>\frac{p_{3}}{j_{3}+2}>\ldots>\frac{p_{3}}{j_{3}+k_{3}} \geq \ldots \geq,
\end{gathered}
$$

gdzie z założenia o wykonalności algorytmu, $j_{1} \geq 1, j_{2} \geq 1$ oraz co najmniej jednen wyraz ciągu $\left(k_{j}\right)$ jest dodatni. Stąd otrzymamy ciąg nierówności:

$$
\frac{p_{1}}{p_{2}} \leq \frac{j_{1}+k_{1}}{j_{2}}, \frac{p_{2}}{p_{3}} \leq \frac{j_{2}+k_{2}}{j_{3}}, \ldots
$$


Podobnie jak w dowodzie lematu, dla ostatniej iteracji algorytmu otrzymamy:

$$
\frac{p_{1}}{p_{2}} \leq \frac{\widetilde{p}_{1}}{\widetilde{p}_{2}}, \frac{p_{2}}{p_{3}} \leq \frac{\widetilde{p}_{2}}{\widetilde{p}_{3}}
$$

Wykorzystamy teraz fakt, że $p_{3}=1-p_{1}-p_{2}$ oraz $\tilde{p}_{3}=1-\tilde{p}_{1}-\tilde{p}_{2}$. Wtedy powyższy układ nierówności będzie można zapisać w postaci równoważnej

$$
\tilde{p}_{1} p_{2} \geq \widetilde{p}_{1} p_{2} \text { i } \tilde{p}_{2}\left(1-p_{1}-p_{2}\right) \geq p_{2}\left(1-\tilde{p}_{1}-\tilde{p}_{2}\right),
$$

co po prostych przekształceniach daje

$$
\widetilde{p}_{2} \geq p_{2} \frac{1-\tilde{p}_{1}}{1-p_{1}}
$$

dlatego

$$
\widetilde{p}_{1} p_{2} \geq p_{1} \widetilde{p}_{2} \geq p_{1} p_{2} \frac{1-\tilde{p}_{1}}{1-p_{1}}
$$

skąd

$$
\widetilde{p}_{1} \geq p_{1} \frac{1-\tilde{p}_{1}}{1-p_{1}} \Leftrightarrow \widetilde{p}_{1}\left(1-p_{1}\right) \geq p_{1}\left(1-\widetilde{p}_{1}\right)
$$

Oczywiście ostatnia nierówność oznacza, że $p_{1} \leq \widetilde{p}_{1}$. Ponadto, z dowodu lematu oraz powyższego rozumowania wynika też, że wartości $\tilde{p}_{1}$ zachowują się jak ciąg niemalejący, to znaczy dla danych dwóch wektorów w, w'

$$
\mathbf{w}=\left(p_{1}, p_{2}, \ldots, p_{k}\right), \mathbf{w}^{\prime}=\left(p_{1}^{\prime}, p_{2}^{\prime}, \ldots, p_{k}^{\prime}\right) \text {, jeśli } p_{1} \leq p_{1}^{\prime} \text {, to } \widetilde{p}_{1} \leq \widetilde{p}_{1}^{\prime} .
$$

Powyższy lemat pozwala sformułować podstawowe twierdzenie o algorytmie D’Hondta.

Twierdzenie (o algorytmie D'Hondta). Przypuśćmy, że dla zbioru skończonego $\mathbf{W}$ oraz liczby naturalnej $k$, $z$ wektorem o malejacych wspótrzędnych $w=\left(p_{1}, p_{2}, \ldots, p_{k}\right)$ wykonat się algorytm D'Hondta dla zbioru $\boldsymbol{M}$. Wtedy na zbiorze $\boldsymbol{M}$ istnieje relacja równoważności określająca jego partycję $\left\{\boldsymbol{M}_{\mathbf{1}}, \mathbf{M}_{2}, \ldots, \boldsymbol{M}_{\boldsymbol{k}}\right\}$ taka, że dla wektora $\boldsymbol{m}$ zdefiniowanego następujaco

$$
\boldsymbol{m}=\left(\frac{\left|M_{1}\right|}{|M|}, \frac{\left|M_{2}\right|}{|M|}, \ldots, \frac{\left|M_{k}\right|}{|M|}\right)=\left(\tilde{p}_{1}, \widetilde{p}_{2}, \ldots, \tilde{p}_{k}\right)
$$

mamy:

1. $\tilde{p}_{1} \geq \tilde{p}_{2} \geq \ldots \geq \tilde{p}_{k}$ oraz $\tilde{p}_{1}+\tilde{p}_{2}+\ldots+\widetilde{p}_{k}=1$

2. $p_{1} \leq \widetilde{p}_{1}$ oraz $\widetilde{p}_{k} \leq p_{k}$;

3. dla wektorów $\boldsymbol{w}, \boldsymbol{w}^{\prime}$, gdzie $\boldsymbol{w}=\left(p_{1}, p_{2}, \ldots, p_{k}\right), \boldsymbol{w}^{\prime}=\left(p_{1}^{\prime}, p_{2}^{\prime}, \ldots, p_{k}^{\prime}\right)$,

$$
\text { jeśli } p_{1} \leq p^{\prime}{ }_{1} \text {, to } \tilde{p}_{1} \leq p_{1}^{\prime} \text {. }
$$


Uwaga 4. Własności 2 i 3 Twierdzenia tłumacza podstawowa własność algorytmu D'Hondta - w warunkach jego wykonalności faworyzowana jest frakcja dominująca w wektorze $\boldsymbol{w}$, co przejawia się w treści relacji równoważności wyznaczającej strukturę podziału mnogości $\boldsymbol{M}$. Daje to możliwość takiej rekonfiguracji partycji zbioru $\boldsymbol{W}$, aby wynik podziału zbioru M przeprowadzony według przyjętej zasady proporcjonalności dla frakcji dominującej, czyli $\widetilde{p}_{1}$, byt najbardziej korzystny. Jednocześnie na margines opłacalności „spychana” jest frakcja najgorsza, czyli $\tilde{p}_{k}$.

\section{Podsumowanie}

Twierdzenie oraz Uwaga 4 pokazują, że algorytm D’Hondta realizuje zapis zasady proporcjonalności sformułowanej w Definicji. Jak wspomniano we wstępie, nie jest to jedyny przykład takiego algorytmu. Znane są też dobrze jego motywy poszukiwania i zasady konstrukcji.

Nie tłumaczy to jednak do końca, dlaczego zasada określenia parytetu struktura głosów oddanych w głosowaniu - struktura podziału mandatów, wykorzystuje potrzebę definiowania macierzy $\mathbf{D}$ oraz zastosowania funkcji wyboru, czyli tego co składa się na algorytm D'Hondta. Wiadomo tylko, co wykazano w Twierdzeniu, że zasada konstrukcji macierzy $\mathbf{D}$ jest warunkiem dostatecznym realizacji zas ady prop orcjo nalności. Dokładniej, dzielenie współrzędnych wektora $w$ przez kolejne liczby naturalne stanowi namiastkę mechanizmu, który próbuje zniwelować efekt nierównoliczności występujących populacji, $\mathrm{w}$ sytuacji nierównolicznych populacji zbioru wyborców oraz zbioru mandatów do obsadzenia, przyjęcie założenia, że wektory $\boldsymbol{w}$ i $\boldsymbol{m}$ są jednakowe, wymagałoby bowiem zawsze korekt co najmniej o charakterze „zaokrągleń", co byłoby niezgodne z oczekiwaniami, jakie powinne wynikać z zasady proporcjonalnego podziału mandatów. Mówiąc wprost - wektor $\boldsymbol{m}$ musi być wynikiem konstrukcji partycji zbioru $\mathbf{M}$, a nie na odwrót.

Można też stwierdzić, że nie ma „złotej” wersji zasady proporcjonalności. Każda z jej implementacji zawiera i będzie zawierała zawsze pewien kompromis, ale też i potencjalną szansę wykorzystania swojego zwycięstwa wyborczego dla co najmniej jednego z graczy. W przypadku algorytmu D’Hondta wiadomo, że jest nim zwycięzca wyborów, a fakt, że ma on zdolność konsolidacyjną, tylko poprawia jego końcowy wynik. Najsłabszy natomiast przegrywa podwójnie, ale jest reprezentowany!

$\mathrm{W}$ tym sensie trudno jest ten mechanizm oprotestować metodami pozamatematycznymi, na co zwracano uwagę już na wstępie pracy.

Należy jednak pamiętać ${ }^{20}$, że wybrana metoda przeliczania mandatów jest tylko jednym z parametrów całej procedury wyborczej, na wynik której mają też wpływ takie czynniki, jak: liczba oraz wielkość okręgów wyborczych oraz rodzaje i wysokości progów wyborczych (tzw. klau zule zap or owe). Jeśli uzupełnić to o czynniki składające się na konstrukcje list wyborczych (strategie wyborcze partii, ich zdolności koalicyj-

20 Zob. J. Raciborski, Teoria demokracji a reguły wyborów, „Nauka” 2006, nr 3, s. 31. 
ne), to obraz wyłaniający się w wyniku przeprowadzonych wyborów w ramach systemu proporcjonalnego może być zaskakujący - rozbieżny z oczekiwaniami realizacji zasady proporcjonalności ${ }^{21}$. Historia polskich wyborów w III RP doskonale to pokazuje, co zostało bardzo wyraźnie przedstawione w pracach Raciborskiego ${ }^{22}$ i Jaczynowskiego ${ }^{23}$.

\section{Bibliografia}

Balinski M., Young H.P., Fair representation, meeting the ideal of one man one vote, Yale University Press, New Haven, CT 1982.

Balinski M., Rachev S.T., Rounding proportions: rules of rounding, „Numer. Funct. Anal. and Optimiz.” 1993, nr 14.

Balinski M., Equitable representation and recruitment, „Ann Oper Res” 2007, nr 149.

Garlicki L., Polskie prawo konstytucyjne - zarys wykładu, Wydawnictwo Liber, Warszawa 1999.

Graham R.L., Knuth D.E., Patashnik O., Matematyka konkretna, Wydawnictwo Naukowe PWN, Warszawa 2002.

Haman J., Podział mandatów pomiędzy okręgi wyborcze w świetle teorii sprawiedliwego podziału, „Przegląd Sejmowy" 2002, nr 1.

Haman J., Badania metod głosowania: dedukcja, indukcja, symulacja, „Decyzje” 2006, nr 6.

Haman J., Degresywnie proporcjonalny podział mandatów w Parlamencie Europejskim. Propozycja nowego rozwiazania, „Decyzje” 2007, nr 8.

Heinrich L., Pukelsheim F., Schwingenschlögl U., On stationary multiplier methods fot the rounding of probabilities and the limiting law of the Sainte-Lagüe divergence, „Statistics \& Decisions” 2005, nr 23.

Holubiec J.W., Mercik J.W., Techniki i tajniki głosowania, Wydawnictwo Omnitech Press, Warszawa 1992.

Jaczynowski L., Mechanizmy organizujące demokracje, , Rocznik Naukowy Wydziału Zarządzania w Ciechanowie" IX, 2015.

Kuratowski K., Wstęp do teorii mnogości i topologii, Wydawnictwo Naukowe PWN, Warszawa 1973.

Lijphart A., Gibberd R.W., Thresholds and payoff in list systems of proportional representation, „European Journal of Political Research" 1977, nr 5.

Michalak B., Pierzgalski M., Wpływ metody przeliczania głosów na mandaty na wyniki wyborów do Sejmu Rzeczypospolitej Polskiej z dnia 23 września 2001 r., [w:] Polska we współczesnym świecie. Między zaściankiem a przestrzenia wolności, red. A. Kasińska-Metryka, R. Bäcker, Torun 2007.

Nohlen D., Prawo wyborcze i system partyjny. O teorii systemów wyborczych, Wydawnictwo Adam Marszałek Scholar, Warszawa 2004.

Petit J., Térouanne E., A theory of proportional representation, „SIAM J. Disc. Math.” 3, 1990, nr 1.

Pierzgalski M., Zastosowanie wybranych metod statystycznych $w$ badaniach systemów wyborczych, „Studia Wyborcze" 9, 2010.

Rae D.W., Hanby V., Loosemore J., Thresholds of representation and thresholds of exclusion: an analyticnote on electoral systems, „Comparative Political Studies” 1971, nr 3.

Raciborski J., Teoria demokracji a reguły wyborów, „Nauka” 2006, nr 3.

Rębowski R., Matematyka dyskretna dla informatyków, Seria Wydawnicza Państwowej Wyższej Szkoły Zawodowej im. Witelona w Legnicy, Legnica 2008.

${ }^{21}$ Na przykład w wyborach z 1993 roku zaobserwowano efekt wyjątkowo dużej dysproporcjonalności.

Z kolei wybory z roku 2001 pokazały skuteczność właściwego zagospodarowania potencjału inżynierii wyborczej polegającą na optymalnym wykorzystaniu możliwości metody D’Hondta, które zostały przedstawione w Twierdzeniu niniejszej pracy. Zob. ibidem, s. 33-37.

22 Ibidem.

${ }^{23}$ L. Jaczynowski, op. cit. 
Rokkan S., Elections: electoral systems, [w:] International Encyclopedia of the Social Sciences, red. D.L. Sills, Macmillan and Free Press, New York 1968.

\section{Źródło internetowe}

Szepietowska B., Zasada proporcjonalności w prawie wyborczym - wybrane systemy rozdzialu mandatów, http://biurose.sejm.gov.pl/teks-ty/i-695.htm

\section{On the D'Hondt principle as a relation defined on unequinumerous populations}

Keywords: equinumerous sets, partition, principle of proportionality, distribution of seats, principle and D'Hondt proportionality algorithm

Summary

A mathematical model of the problem of dividing two unequinumerous populations based on the partition of one of them was constructed. It has been shown that the division meets the requirements formulated in the criterion called the principle of proportionality, which is a mathematical version of the widely used in political science principle of the distribution of seats based on the D'Hondt method. 